\title{
AURIFERITY OF THE PHANEROZOIC SEDIMENTARY DEPOSITS OF THE UKRAINE M.S. Koval'chuk
}

\section{ЗОЛОТОНОСНІСТЬ ОСАДОВИХ УТВОРЕННЬ ФАНЕРОЗОЮ УКРАЇНИ М.С. Ковальчук}

Analysis auriferity of the phanerozoic sedimentary deposits of the Ukraine is given. The auriferity lithophacial and facial complexes are established. Analisys of gold distribution in sedimentary complexes of Ukraine gave the opportunity to set up progressive formation units. The main role in creation of gold potential of sedimentation cover belongs to the complex of sedimentation formations which were developed in very alite environment of sediment accumulation. They are greatly introduced all over the territory of Ukraine. The perspective strata for exploration placer gold qre recorded.

Key words: Ukrainian, auriferity, sedimentary deposits, auriferity lithofacies, facies and formstions units.

Проведено аналіз золотоносності осадових утворень фанерозою України. Встановлено золотовмісні літофаціальні і фаціальні комплекси. Аналіз розподілу золота в осадових утвореннях України дозволив виявити перспективні формаційні одиниці. Провідну роль у створенні золотого потенціалу осадового чохла відіграє комплекс осадових формацій, що утворилися в близьких за умовами осадконагромадження обстановках і мають значне поширення на території України. Встановлено перспективні осадові товщі для видобування розсипного золота.

Ключові слова: Україна, золотоносність, осадові утворення, золотоносні літофації, фації, формаційні одиниці.

\section{ПОСТАНОВКА ПРОБЛЕМИ}

Територія України тривалий час вважалась безперспективною на золото, хоча його знахідки і перекази про видобування металу відомі ще з сивої давнини. За часів існування колишнього СРСР перспективи золотоносності України не мали державного значення і певною мірою не оцінювалися, оскільки на території супердержави були інші регіони, де вже протягом тривалого часу відбувалося рентабельне видобування металу. Лише в Закарпатському регіоні з 70-х років минулого століття почалися роботи з вивчення золото-поліметалічних родовищ Мужієвське і Сауляк. Після розпаду СРСР та зі здобуттям Україною незалежності ситуація різко змінилася, оскільки від об'ємів валютних запасів і видобутку золота значною мірою залежить економіка і розвиток багатьох країн світу, в тому числі й України. Тому з перших років незалежності Україна почала створювати власну золотодобувну промисловість. Створення золотовидобувної промисловості неможливе без всебічної оцінки сировинної бази. За короткий термін було встановлено, що Україна володіє достатньо потужним золотрудним потенціалом. На жаль, оцінка золотоносного потенціалу осадового чохла мала підпорядкований характер. Величезне значення для оцінки потенціалу золотоносності осадових товщ $є$ встановлення золотовмісних літофацій і фацій, їх просторового і часового розподілу, формаційної належності золотовмісних товщ.

\section{АНАЛІЗ ПОПЕРЕДНІХ ДОСЛІДЖЕНЬ}

Дослідженню золотоносності осадового чохла фанерозою окремих регіонів України присвячено чимало робіт [1-38], однак публікацій узагальнюючого плану не так вже й багато. Серед останніх необхідно відмітити праці С.В. Яблокової та Ю.О. Полканова [38], М.П Семененка із співавторами [35] та М.С. Ковальчука $[18,19]$.

Метою роботи був аналіз золотоносності осадових утворень фанерозою України і на базі цього встановлення золотовмісних літофаціальних і фаціальних комплексів, формаційних одиниць, виявлення перспективних товщ для можливого видобування розсипного золота.

\section{ВИКЛАД ОСНОВНОГО МАТЕРІАЛУ}

Золото в осадових відкладах палеозойської групи встановлено в утвореннях кембрійської, силурійської, девонської, кам'яновугільної і пермської систем. У кембрійській системі метал виявлено в аргілітах, пісковиках західного схилу Українського щита (УЩ). Золотоносними є карбонатні відклади силуру в межах Волино-Подільської плити. В девонській системі золотоносними є аргіліти західного схилу УЩ; вапняки, глинисті сланці, алевроліти, пісковики Добруджя; пісковики, туфопісковики, 
аргіліти, туфоалевроліти та галогенні породи Дніпровсько-Донецької западини (ДДЗ). В кам'яновугільній системі прояви золота виявлено в аргілітах ДДЗ; глинистих сланцях, аргілітах, алевролітах, вугіллі, пісковиках, гравелітах, дрібногалечних конгломератах, строкатоколірних, теригенно-чорносланцевих і карбонатних породах Донбасу; вуглецевисто-глинистих сланцях (з прошарками алевролітів, пісковиків, вапняків) Добруджя. В пермській системі золото встановлено в глауконіт-кварцевих пісках, мідистих пісковиках Донбасу; строкатоколірних конгломератах (з прошарками аргілітів, пісковиків, вапняків) Карпат та конгломератах о-ва Зміїний у Чорному морі.

В генетичному плані золотовмісні осадові утворення палеозойської групи утворились в умовах морських, прибережно-морських, алювіальних, делювіальних фаціальних обстановках, де поряд 3 кластогенним відбувалось хемогенне концентрування золота в осадках вже на стадії седиментогенезу. Більшість утворень палеозойської групи зазнала різного ступеня постседиментаційних змін, в результаті яких відбувся перерозподіл металу в мінералах і породі, утворилась гідротермальна золоторудна мінералізація. В осадових комплексах палеозою Карпатського регіону вміст золота досягає

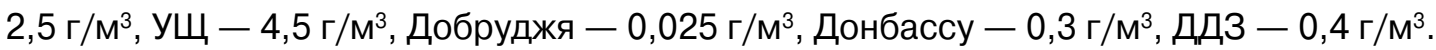

В осадових комплексах мезозойської групи золото виявлено в утвореннях тріасової, юрської і крейдової систем. У тріасовій системі золотоносними є конгломератоподібні глинисто-піщані відклади ДдЗ та Донбасу; аргіліти, пісковики, конгломерати, доломіти, вапняки Рахівського і Чивчинського кристалічних масивів Карпат; конгломерати, пісковики, алевроліти Добруджя. Золото в утвореннях юрської системи встановлено в конгломератах Рахівського масиву Карпат; конгломератах, галечниках, пісках, пісковиках Донбасу; конгломератах, пісках Причорноморської западини; конгломератах Криму; пісковиках Добруджя. В крейдовій системі золотоносністю характеризуються піски, гравеліти, галечники, первинні та вторинні каоліни, каолінові глини УЩ; конгломерати, пісковики, породи флішу Карпат; кременисті породи, піски Волино-Подільської плити; піски Криму; мергелі та крейда Донбасу. В генетичному плані золотоносні осадові відклади представлені елювіальними, делювіальними, пролювіальними, алювіальними, прибережно-морськими і морськими фаціями. Характерною особливістю золотоносних осадових комплексів мезозойської групи є те, що, на відміну від більш древніх, їх не торкнулись процеси метаморфізму. Особливо необхідно відмітити широкий розвиток у мезозої площових і лінійних кір хімічного вивітрювання на золотоносних породах, які найбільш поширені в межах УЩ (меншою мірою в Добруджі, Донбасі і ДдЗ та збереглися (частково чи повністю) до наших днів. Вміст металу в осадових товщах мезозойської групи досягає промислових значень і становить інколи 2,3 та 12,0 г/ $\mathrm{M}^{3}$.

Розсіяна мінералізація золота притаманна практично усім осадовим утворенням кайнозою. В палеогеновій системі золотоносними є породи флішу, пісковики, міденосні пісковики, гравеліти, конгломерати, карбонатно-кременисті породи Карпатського регіону; буре вугілля, вуглисті глини, вуглецьвмісні алевроліти, вторинні каоліни, піски, гравійно-галечні відклади Ущ; пісковики, піски Донбасу; мергелі та суглинки Середнього Придністров'я; піски дДЗ. Неогенова система характеризується наявністю золота в алевролітах, аргілітах, пісковиках, гравелітах, конгломератах Карпатського регіону; лесах, глинах, пісках, піщано-глинистих і гравійно-галечних відкладах УЩ; пісках Середнього Придністров'я; пісках Добруджя; пісках ДДЗ; галечниках Донбасу; глинах, мулах, пісках Чорноморського басейну. Досить велике поширення проявів золота спостерігається в осадових товщах четвертинної системи. В межах УЩ золото виявлено в лесах, викопних ґрунтах, мулистих суглинках, делювіальних, делювіально-пролювіальних утвореннях, а також в алювії рік Ірша, Тетерів, Рось, Синюга, Собі, Жовта, Саксагань, Інгулець, Дніпро, Берда, Обіточна, Берестова, Кільтичія, Чокрак, Конка та ін. В Донбасі золотоносність антропогену представлена знахідками золота в алювії річок Нагольна, Кринка, Міус, Крепенька, Середня Тузлова та в делювіальних (балки Безіменна, Агуєвська, Сотова, Дубравка та ін.), меншою мірою елювіальних відкладах. У межах Волино-Азовської плити найбільш відомі знахідки золота в алювіальних осадках середньої течії р. Дністер, його давніх терасах і алювії його лівих приток. У Північному Причорномор'ї золотопрояви притаманні відкладам прибережноморських і лиманних груп фацій антропогену і пов'язані з піщаними літофаціями (Коктебельська бухта, район Кароліно-Богаз). В Криму розсипне золото встановлено в піщаних відкладах алювію річок Чорна, Бельбек, Кача, Ангара, Салгір та ін., а також у пляжних галечниках Судацької затоки. Найбільшого розвитку четвертинні прояви золота набули у Карпатському регіоні. Четвертинні розсипи золота приурочені до русел сучасних рік та їх приток. Найбільш відомі прояви розсипного золота в 


\section{ЗОЛОТОНОСНІСТЬ ОСАДОВИХ УТВОРЕННЬ ФАНЕРОЗОЮ УКРАЇНИ}

алювії рік Чорний і Білий Черемош, Уж, Тиса, Ріка, Латориця, Прут, Пістинка, Лючка, Стрий, Дністер, струмків Солонцовка, Перкалаб, Маскотин, Ластун, Альбін, Дземброня, Ільця, Ведмежий, Насарат, Ключевка, Кошелівка та ін.

В генетичному плані золотоносні осадові відклади кайнозою представлені елювіальними, делювіальними, пролювіальними, алювіальними, прибережно-морськими і морськими фаціями. Вміст

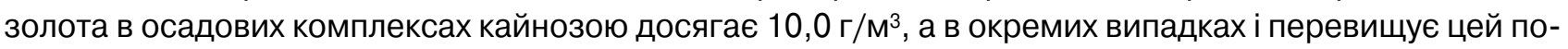
казник.

Таким чином, на сьогоднішній день золото виявлено в усіх літолого-стратиграфічних горизонтах фанерозою, які утворились у різних структурно-тектонічних, кліматичних, геоморфологічних та фаціальних обстановках. Це поодинокі його знаки та шліхові аномалії, точки мінералізації в осадових товщах і навіть розсипні рудопрояви. Вміст золота в осадових товщах коливається в широких межах і в окремих випадках досягає промислових значень.

Провідну роль у створенні золотого потенціалу осадового чохла відіграє комплекс осадових формацій, які утворились в близьких за умовами осадконагромадження фаціальних обстановках і досить широко представлені на території України.

Значний золотоносний потенціал зосереджений в конгломератах, що широко розвинуті в різних золотоносних районах України. В Закарпатському прогині - це верхньопермські конгломерати, в Складчастих Карпатах - конгломерати середньотріасового, пізньоюрського та ранньопалеогенового віку, в Передкарпатському прогині - нижньопалеогенові та неогенові конгломерати, в Добруджі конгломерати нижнього-середнього тріасу, в ДдЗ - тріасові конгломерати. Сприятливою зоною для формування золотого зруденіння типу давніх конгломератів є перехідна між областями денудації та акумуляції палеозона, при умові досить високої загальної золотоносності першої. Такий висновок випливає з двох причин, що пов'язані з літолого-фаціальними особливостями даної зони: акумуляцією тут значних мас тонкого вільного і дисперсного золота; доброю фільтрацією піщано-гравійногалечних відкладів цієї зони, що визначає можливість проходження в широких масштабах мобілізації і перевідкладення золота гідротермальними розчинами.

Одним з найперспективних і масштабних формаційних типів золотоносних проявів є гіпергенний, який представлений різновіковими площадними та лінійними корами вивітрювання (монтморилонітовими, каолінітовими, гідрослюдистими, інколи латеритними та ін.), зонами окислення сульфідовмісних порід і руд та карстовими системами. Золотоносні гіпергенні утворення широкого розвитку набули в межах території УЩ, Донбасу, Українських Карпат, Криму.

Широко розвинуті зони гіпергенезу і на відомих рудовищах і рудопроявах золота. Так, у межах Клинцівського, Майського, Юр'ївського рудовищ гіпергенні процеси слабкі і потужність елювію невелика. Значно більші масштаби гіпергенезу проявлені на рудопроявах Сергіївське, Капітанівське, Балка Широка, Бобрикове. Інколи золотоносні лінійні кори вивітрювання успадковують крутопадаючі тектонічні порушення, що контролюють ендогенну золоту мінералізацію (Капітанський рудопрояв, Савранське рудне поле). Інтенсивна і різноманітна за речовинно-генетичним складом гіпергенна золота мінералізація розвинута на золоторудних об'єктах Закарпаття і Донбасу. Різноманітна історія геологічного розвитку регіонів України та окремих блоків УЩ обумовила різний ступінь збереженості зон гіпергенезу і, відповідно, їх перспективність на золоте зруденіння.

Певний інтерес становлять гіпергенні перетворення порід вуглецевистих формацій, які містять первинні концентрації золота. Такі комплекси розвинуті в Донбасі (вуглецевисто-теригенні утворення карбону) та ін. Гіпергенні прояви золота встановлені також при вивітрюванні бітумвмісних порід Перечин-Саймівського, Оленівського, Вишківського та інших районів Українських Карпат [24]. Золотоносною є також кора вивітрювання експлозивних утворень УЩ (Інгулецький, Хащевато-Заваллівський райони, Балка Північно-Червона та ін.). Серед гіпергенних проявів золота карстового типу заслуговують на увагу карбонатні породи Донбасу, Волино-Подільської плити, Передкарпатського прогину, Криму [24].

Перспективним геолого-промисловим типом гіпергенних концентрацій золота в Україні, на думку Є.О. Куліша є також зони окислення і цементації різноманітних сульфідовмісних зон у первинних породах (особливо, коли вони поєднуються з карбонатними або вуглецьвмісними породами) [24]. Подекуди формуються золото-залізо-марганцеві землисті руди (Українські Карпати, Чивчинський район). 
В межах території України глинисті золотоносні кори вивітрювання мають тісний просторовий і генетичний зв'язок з давніми алювіальними розсипами, що характеризуються значним вмісом глинистої складової. Це дозволяе говорити про прояви золота формації кори вивітрювання, яка складається з єдиного еволюційно-генетичного ряду гіпергенних рудопроявів: залишкові (кори вивітрювання) і осадові прояви розсипного і тонкодисперсного золота.

В тісній асоціації з корами вивітрювання та континентальними розсипами знаходяться прибережно-морські золотоносні розсипи, які широко розвинуті в межах Складчастих Карпат (утворення середнього тріасу і верхнього палеогену), Передкарпатського прогину (верхньокрейдові, нижньопалеогенові та неогенові відклади), Придніпров'я (неогенові), дДЗ (неогенові), Донбасу (середньоюрські та палеогенові утворення), північно-західного Причорномор'я (неогенові та сучасні) та ін. Серед них особливе місце посідають комплексні титано-цирконієві розсипи з золотом, що утворились в результаті багаторазового перемиву металоносних відкладів в умовах внутрішніх морських басейнів (прибережно-морські фації). Золото виявлено як в сучасних (північно-західне Причорномор'я), так і в давніх (переважно неогенових розсипах ДДЗ та Придніпров'я) титано-цирконієвих розсипах.

Певним золотоносним потенціалом характеризуються різновікові фосфоритоносні товщі, які містять родовища і прояви фосфоритів. За даними ряду дослідників, фосфорити - добрий концентратор золота [16]. Окрім цього, фосфоритоносні літофації, як правило, містять каолініто-гідрослюдистий цемент, з включенням сульфідів, гідроксидів заліза та тонкорозпиленою органікою, які разом $з$ глинистими мінералами концентрують гідрогенне та тонкодисперсне золото. Золотовмісні прояви фосфоритів найбільше розповсюджені в верхньопротерозойських (Середнє Придністров'я), верхньокрейдових (Донбас, Волино-Подільська плита) і палеогенових (ДДЗ, Донбас) відкладах. Досить часто парагенетичну асоціацію з фосфоритами утворює глауконіт, який, як і фосфорити, є активним концентратором золота. Слід зауважити, що значну роль в золотоносності цих формаційних одиниць має факт ї залягання (здебільшого) на корі вивітрювання порід кристалічного фундаменту, що містить як кластогенне, так і гідрогенне золото.

Провідне значення в золотоносному потенціалі країни мають чорносланцеві формаційні комплекси (різноманітні за літологічним складом і геодинамічними обстановками формування), утворення яких відбувалось в різному часовому діапазоні (від докембрію до неогену) і які досить широко розповсюджені на території України [4]. Велика потужність та широкий спектр літогенетичних перетворень цих порід обумовили багатоступеневий процес перерозподілу та концентрації в них золота, в результаті якого золотоносність їх представлена декількома генетичними типами (син-, діа-, епігенетичним). Найбільш вивченими і перспективними з них є чорносланцеві утворення карбону Донбасу, тріасу Криму, крейди-палеогену Українських Карпат та крейди в межах акваторії Чорного моря. Чорносланцеві товщі, які вміщують золото, мають специфічні риси, а саме: переважання алевритових і дрібнопсамітових різновидів над пелітовими і псефітовими; простий мінеральний склад руд; незначний домішок карбонатного матеріалу; наявність тонкодисперсної вуглецевистої речовини в невеликих кількостях (до $2 \%$ ); наявність розсіяного осадово-діагенетичного піриту декількох (як правило чотирьох) генерацій [4]. В чорносланцевих товщах України виявлено прояви золота золото-сульфідного, золото-кварцсульфідного, золото-кварцевого та інших формаційних типів.

Нетрадиційний тип золотого зруденіння в вуглецевистих породах виявлено давно і достатньо добре вивчено. В останні роки за кордоном і в нашій країні у збагачених органічною речовиною породах поряд з золотом виявлено значний вміст елементів платинової групи. Так, у Польщі в мідистих пісковиках цехштейну встановлено золото-платинову мінералізацію. Ознаки золотої мінералізації виявлено в подібних літокомплексах України [3].

Важливу роль в золотоносному потенціалі осадового чохла відіграють моласові і моласоподібні формаційні одиниці, які сформувалися в межах крайових платформних прогинів. Моласові басейни золоторудних провінцій - це великі ресурси самородного золота. Золоторозсипні моласові басейни формувались в періоди орогенезу геосинклінально-складчастих поясів, що супроводжувались роздробленням, інтенсивною денудацією, ерозією золотопроявів. При орогенезі з гірських хребтів, що здіймались, зносилась величезна кількість уламкових золотовмісних утворень, які могутніми водними потоками транспортувались в передгірські моласові басейни. Могутні потоки сприяли дезінтеграції золотовмісних уламкових утворень, а синхронне чергування фаз орогенезу, епейрогенезу і консолідації тектонічної обстановки супроводжувались гравітаційною диференціацією теригенно-кон- 
гломератових відкладів у басейнах акумуляції. Для моласових товщ характерний широкий розвиток конгломератів, що, як правило, залягають в нижній частині моласової товщі і містять кластогенне золото. Перспективними в цьому відношенні є пермські моласоподібні утворення Донбасу, юрські Придобрудзького прогину, неогенові Передкарпатського прогину. Окрім розсипного золота, моласові товщі містять значну кількість пилоподібного і тонкодисперсного золота. Загальні прогнозні ресурси золота в моласових басейнах України можуть становити кілька тисяч тонн.

Значний золотоносний потенціал (з урахуванням розсипного) містять червоноколірні субформації та формації, що нагромаджувались в умовах континентального осадконагромадження в межах приморських алювіальних рівнин і платоподібних вододільних просторів. Червоно- і строкатоколірні породи, що сформувались в аридних і напіваридних зонах, як правило, не містять розсипів золота, хоча характеризуються підвищеною золотоносністю (зокрема міденосні осадові формаційні одиниці Українських Карпат, Донбасу та ін.). Утворення відкладів відбувалось в результаті виносу і перевідкладення уламкового матеріалу (в тому числі кір вивітрювання) з областей живлення, що підіймались на регресивній або кінцевій стадії седиментаційного циклу розвитку. Перспективними в цьому плані є червоноколірні товщі Волино-Подільської плити (нижній девон), дДЗ та Донбасу (верхній девон, верхня перм, верхній тріас), Придобрудзького прогину (верхня юра), Українських Карпат (верхній тріас, верхня крейда, палеоген (еоцен)), Передкарпатського прогину (неоген). Встановлено два типи золотоносності червоноколірних товщ, які зумовлені літологічними особливостями рудоносних відкладів з переважанням на одних об'єктах псамітових (мідисті пісковики), а на інших алевритових і глинистих порід. Мігруючи у суспендованому стані, золото збагачувало як континентальні товщі, так і мілководно-морські осадки. Ритмічна будова червоноколірних товщ обумовила багатоярусне розташування рудоносних тіл. Процеси оглеєння червоноколірних товщ обумовили міграцію, перерозподіл та концентрацію золота та утворення значних і витриманих по простяганню золотовмісних горизонтів. В підошві червоноколірних товщ, які залягають на зеленувато-строкатоколірних міденосних моласах,відмічаються лінзи галечних конгломератів руслового палеоалювію, з якими можуть бути пов'язані золотоносні розсипи.

Сприятливими для нагромадження тонкодисперсного і гідрогенного золота є області формування вугленосних формаційних одиниць, які в межах України просторово пов'язані з золотоносними регіонами, а у віковому діапазоні - з формуванням в цих регіонах золотоносних осадових товщ. У вугленосних товщах головним чином відбувалась концентрація на відновних геохімічних бар'єрах тонкодисперсного золота. Окрім садки на відновному геохімічному бар'єрі, тут, вірогідно, золотоносність обумовлена і поствулканічною діяльністю, зокрема газовими еманаціями в проникні осадові товщі. Вуглепрояви та родовища вугілля досить широко розповсюджені на території України, а найбільш перспективні локалізовані в межах ДдЗ (відклади девону, нижнього і середнього карбону, юри, крейди, палеоген-неогенові), Донбасу (утворення девону, карбону, юри, крейди), Придобрудзького прогину (нижній карбон, неоген), Передкарпатського (нижній-середній карбон, неоген) і Закарпатського (неоген) прогинів, Складчастих Карпат (неогенові відклади), УЩ (утворення юри, крейди, палеогену), Придністров'я (неоген) та в Криму (середньоюрські відклади).

Певний інтерес з точки зору золотоносності становлять евапоритові групи формацій, які утворились у внутрішньоконтинентальних солеродних басейнах. Перспективними $є$ солі Стебникського родовища та зруденіння, що пов'язані з Білявською, Новодмитрівською і Степковською солянокупольнми структурами. Золотоносність евапоритових формаційних одиниць, вірогідно пов'язана 3 діяльністю галобактерій, які обумовлюють концентрацію золота.

Карбонатні товщі України майже зовсім не вивчені на золото, хоча досить широко розповсюджені у різновікових формаційних комплексах. Основний золотоносний потенціал карбонатних комплексів пов'язаний з розсіяною золотою мінералізацією (тонкодисперсне золото), меншою мірою з мінералізованими жилами, лінзами та прожилками гідротермального походження. Найбільш перспективними у плані золотоносності є карбонатні породи Закарпатського прогину, Волино-Подільської плити, Волинського та Кіровоградського блоків УЩ, Кривбасу, Побужжя, а також карбонатні породи Південного Донбасу та Гірського Криму [25].

Підвищені концентрації золота відмічаються в осадках, збагачених пірокластичним матеріалом. В межах України пірокластичні породи відомі з архею до нашого часу, однак їх розподіл дуже нерівномірний як у геологічному розрізі, так і в різних геолого-структурних районах. Виділяють певні геологічні епохи, які характеризуються максимальним розвитком експлозивної діяльності на території України. Найбільш давні, 
палеозойські пірокластичні породи відомі на південно-західному схилі УЩ (девон - карбон), в Донбасі, ДДЗ і в Рахівському кристалічному масиві (Українські Карпати); молоді (кайнозойські) пірокластичні породи виявлені в Передкарпатському і Закарпатському прогинах. В результаті гальміролізу вулканічного попелу in situ, що протікав у відновному середовищі (про це свідчить наявність в глинах тонкорозпилених сульфідів заліза, а іноді й марганцю), утворились бентонітові глини, де тонкодисперсне золото зв'язувалось з сульфідами заліза, гідроксидами марганцю або сорбувалось глинистими новоутвореннями.

Заслуговують на увагу і кременисті формаційні комплекси, в яких виявлено незначні концентрації золота. Такі формаційні комплекси дуже поширені в Карпатському регіоні та в межах ВолиноПодільської плити. Їх утворення відбувалось в морських басейнах, а золотоносність, мабуть, пов'язана з вулканічною діяльністю. Розчинене в морській воді золото сорбувалось кремнеземом під час утворення кременистих порід.

Значний практичний інтерес становлять сучасні алювіальні відклади. В них на сьогоднішній день встановлені численні прояви і рудопрояви розсипного золота. Хоча золотоносні розсипи не завжди витримані як за потужністю, так і по простяганню, однак в них відмічаються ділянки зі значним, промисловим вмістом металу. Запаси золота на таких ділянках становлять десятки і навіть сотні кілограмів. Враховуючи умови залягання і технологію збагачення розсипів, за допомогою невеликих мобільних збагачувальних установок можна вести напівпромислове і промислове видобування золота. Такі розсипи поширені в межах Закарпатського і Передкарпатського прогинів, Складчастих Карпатах, Волино-Поділлі, ущ і частково Донбасі.

\section{ВИСНОВКИ І ПЕРСПЕКТИВИ ПОДАЛЬШИХ ДОСЛІДЖЕНЬ}

Зважаючи на слабкий економічний потенціал молодої незалежної держави, перспективи розвитку золотовидобувної промисловості, на нашу думку, слід пов'язувати з осадовими товщами, з яких можна швидко, екологічно чисто та економічно вигідно видобувати метал. Незважаючи на широке розповсюдження розсипного золота, певний промисловий інтерес на сьогоднішній день становлять лише палеорозсипи золота в нижньокрейдових і еоценових відкладах УЩ; палеорозсипи золота в пермських, крейдових, палеогенових і неогенових відкладах Українських Карпат; розсипи залишкового золота в корах вивітрювання над золоторудними об'єктами в межах УЩ, Побужжя і Донбасу; розсипи золота в сучасних континентальних (головне річкових) відкладах Українських Карпат. Пухкість і слабка консолідація осадових товщ, екологічно чиста і проста технологія збагачення самородного золота, застосування відходів виробництва в будівництві, унікальні ресурси самородного золота в осадових басейнах і значна мінерально-сировинна база - все це може забезпечити високі прибутки при видобуванні самородного золота 3 порід осадового чохла.

1. Аверин Ю.А., Зарицкий А.И., Лебедь Н.И. и др. Перспективы золотоносности территории Украины // Геол. журн. - 1992. - №4. - С. 38-44.

2. Артеменко В.М., Лебідь М.І. Золото-ртутне зруденіння в карбонатних породах Докучаївського рудного району, Південний Донбас // Мінер. ресурси України. - 1996. - № 1. - С. 14-17.

3. Артеменко В.М., Коваль В.Б. Первые находки платиносодержащего золота в разновозрастных золоторудных формациях Украины и их прогнознометаллогеническое значение // Проблемы золотоносности недр Украины. - Киев, 1997. C. 71-81.

4. Афанасьєва І.М. Прояви золота в фанерозойських чорнолупакових формаціях України // Золотоносність осадових і метаосадових комплексів України. - К., 1995. - C. 5-17.

5. Белоконь В.Г., Бланк М.Я., Никитин Н.М. и др. О россыпном золоте мезокайнозойских отложений северных окраин Донбасса // Геол. журн. - 1974. Т. 34, № 4. - С. 109-113.

6. Бобриевич А.П., Грищик Е.П., Грищик В.В. Вопросы золотоносности Чивчинских гор и Прикарпатья // Геология и вещественный состав руд месторождений Украины. - М., 1971. - С. 75-81.

7. Брагин Ю.Н., Полканов Ю.А. Морская россыпь золота в Восточном Крыму // Геология и полезные ископаемые Черного моря. - Киев, 1999. - С. 204-207.

8. Грицик В.В., Грицик Е.П., Матковский О.И. О самородном золоте из верховьев Белого Черемоша // Минерал. сб. Львов. ун-та. - 1968. - № 22, вып. 4. С. 386-393.

9. Грицик В.В., Грицик Е.П., Матковский О.И., Яблокова С.В. О самородном золоте из конгломератов соймульской свиты в Чивчинских горах Карпат // Там же. - 1972. - № 26, Вып. 4. - С. 403-405.

10. Дзюба С.М., Лепкий С.Д. Золотоносность терригенных отложений и угольных пластов Донецкого 
бассейна // Состав, происхождение и размещение осадочныхпород и руд. - Киев: Наук. думка, 1981. С. $164-168$.

11. Заруцкий К.М., Ветров Ю.И., Злобенко И.Ф. и др. О находке золота в аллювии погребенных раннемеловых долин центральной части Украинского щита // Геол. журн. - 1980. - Т. 40. - №3. - С. 149-151.

12. Заруцкий К.М., Ветров Ю.И. Злобенко И.Ф. и др. Находка золота в аллювий погребенных раннепалеогеновых речных долин центральной части Украинского щита // Геол. журн. - 1981. - Т. 41, вып. 5. С. $155-156$.

13. Заруцкий К.М. Золото в мезо-кайнозойском осадочном покрове и коре выветривания докембрийских пород центральной части Украинского щита // Геохимия и рудообразование. - 1989. - №12. - С. 89-92.

14. Кардаш В.Т. Золотоносность северо-восточного склона Украинских Карпат // Тектоника и полезные ископаемые запада Украинской ССР. - Киев.: Наук. думка, 1973. - С. 42.

15. Кардаш В.Т., Лебедь Н.И., Яценко Ю.Г. Золотоносность донных осадков Азовского моря // Мінер. ресурси України. - 1996. - №3. - С.10-11.

16. Коваленко Д.Н., Латыш И.К. О золотоносности фосфоритоносных отложений Украины // Геол. журн. 1973. - Т. 33, вып. 6. - С. 144-145.

17. Ковальчук М.С. Золото з різновікових кір вивітрювання України // Геол. журн. - 2000. - №2. - С. 39-43.

18. Ковальчук М.С. Золотоносність осадових комплексів України // Мінерал. Зб. Львів. ун-ту. - 2001. - № 51, вип. 1. - С. 75-87.

19. Ковальчук М.С. Перспективні осадові золотоносні формаційні комплекси України // Аспекти геологічної науки на рубежі тисячоліть. - К., 2001. - С. 4-11.

20. Кравченко Г. Л. Золото в осадочном чехле Приазовья // Геол. журн. -- 1994. - № 3. - С. 117-121.

21. Кравченко Г. Л., Сахацький І. І. Про присутність золота і срібла в мідистих пісковиках Донбасу // Там же. 1975. - Т. 35, № 1. - С. 114-118.

22. Кузнецов Ю.А., Панов Б.С., Стрекозов Н.Ф. О самородном золоте из каменноугольных отложений // Минерал. сб. - 1981. - № 35, вып. 2. - С. 29-33.

23. Кузнецов Ю.А., Сущук Е.Г., Копылова Л.В., Лагутин П.К. Распределение золота в осадочных, вулканогенно-осадочных и магматических формациях ДоноДнепровского прогиба / АН УССР. ИГФМ. - Препр. Киев, 1981. - 30 с.

24. Кулиш Е.А., Комов И.Л., Лебедь Н.И. Вещественногенетические типы гипергенных концентраций золота и их перспективы в Украине // Проблемы золотоносности недр Украины. - Киев, 1997. - С. 245-276.

Institute of Geological Sciences NAS Ukraine, Kyiv, Ukraine Інститут геологічних наук НАН України, м. Київ, Україна
25. Лебідь М.І. Золоте зруденіння у карбонатних породах Південного Донбасу та інших регіонів України // Мінер. ресурси України. - 1995. - № 2. - С. 8-13.

26. Лепкий С.Д., Колесникова А.А. Золотоносность стратифицированной карбонатно-углеродистой формации Черного моря // Тр. І Всесоюз. совещ. «Условия образования и закономерности размещения стратиформных месторождений редких и благородных металлов» (24-27 сент. 1985, Фрунзе). - Фрунзе 1985. - С. 328-330.

27. Маслаков Н.А. Верхнеплиоценовая река на Керченском полуострове // Геология и полезные ископаемые Черного моря. - Киев, 1999. - С. 255-261.

28. Матковський О.І. Родовища і рудопрояви золота Українських Карпат // Вісн. Львів. ун-ту. Сер. геол. 1992. - Вип. 11. - С. 96-120.

29. Мельничук Э.В., Павлюк В.Н. Золото Побужья и Приднестровья // Минерагения и прогнозная оценка на твердые полезные ископаемые. -Киев, 1991. Вып. 2. - С. 23-24.

30. Мельничук Э.В., Гурский Д.С., Павлюк В.Н. и др. Проявление гипергенного золота в Побужском районе Украинского щита // Геол. журн. - 1992. - № 4. C. $126-128$.

31. Панов Б.С. Про металогенію золота в Донбасі // Вісн. Львів. ун-ту. Сер. геол. - 1994. - Вип. 12. - С. 46-64.

32. Паранько И.С. Перспективы золотоносности докембрийских конгломератов Украинского щита // Геол. журн. - 1992. - № 4. - С. 48-55.

33. Полканов Ю.А., Яловенко И.П. О находках золота в прибрежно-морских и лиманных песках северозападного побережья Черного моря // Докл. АН CCCP. - 1970. - Т. 191, № 4. - С. 905-908.

34. Резник В.П. Некоторые закономерности формирования скоплений тонкого золота на шельфе Черного моря // Геол. журн. - 2001. - №4. - С. 110-117.

35. Семененко Н.П., Оставненко А.И., Кузнецов Ю.А., и др. Золотоносные россыпи Украины // Древние и погребенные россыпи СССР. - Киев: Наук. думка, 1977. - Т. 2. - С. 35-42.

36. Хрипков Л.В., Зайцев О.А. Про золотоносність кори вивітрювання в Середньому Придністров'ї // Геол. журн. - 1973. - Т. 33, вип. 4. - С. 132-134.

37. Шнюков Е.Ф. Поиски месторождений мелкого и тонкого золота в Азово-Черноморском регионе - важная геологическая проблема XXI века // Геологические проблемы Черного моря. - Киев, 2001. - С. 11-22.

38. Яблокова С.В., Полканов Ю.О. Золото титаноносних розсипищ України // Доп. АН УРСР. Сер. Б. - 1974. № 8. - С. 701-703. 